\title{
Hypocalcemia-Cow-level prevalence and preventive strategies in German dairy herds
}

\author{
P. L. Venjakob, ${ }^{*} \dagger$ S. Borchardt, ${ }^{*}$ and W. Heuwieser ${ }^{* 1}$ \\ ${ }^{*}$ Clinic for Animal Reproduction, Faculty of Veterinary Medicine, Freie Universität Berlin, 14163 Berlin, Germany \\ †Veterinary Practice G. Thiele, Baruth, Germany Koenigsweg 65, 14163 Berlin, Germany
}

\begin{abstract}
Hypocalcemia around calving is considered a gateway disease that can lead to health disorders and decreased milk production. The objective of this cross-sectional study was to evaluate the prevalence of clinical and subclinical hypocalcemia 0 to $48 \mathrm{~h}$ after calving. Blood samples were drawn from 12 animals of each dairy farm $(\mathrm{n}=115)$ and analyzed for serum calcium, magnesium, and phosphorus concentration. Cows not affected clinically but with a serum calcium concentration below $2.0 \mathrm{mmol} / \mathrm{L}$ were characterized as subclinical hypocalcemic animals. Recumbent cows with a serum calcium concentration below $2.0 \mathrm{mmol} / \mathrm{L}$ were defined as cows suffering from clinical milk fever. Herds were classified into negative (0 to $2 / 12)$, borderline (3 to $5 / 12)$, and positive $(\geq 6 / 12)$ according to the number of animals with hypocalcemia. Strategies to control hypocalcemia were documented. Prevalence of clinical milk fever was $1.4,5.7$, and $16.1 \%$ for second, third, and $\geq$ fourth parity cows, respectively. None of the cows in first lactation were suffering from clinical milk fever. Based on the threshold of $2.0 \mathrm{mmol} / \mathrm{L}, 5.7,29.0,49.4$, and $60.4 \%$ of cows in first, second, third, and $\geq$ fourth lactation were suffering from subclinical hypocalcemia, respectively. Fourteen, 51, and 50 herds were classified as negative, borderline, and positive, respectively. A positive association was observed between serum calcium and serum phosphorus concentration. Serum calcium and magnesium concentration were negatively associated. Only 50 of 115 farms had a control strategy implemented to avoid hypocalcemia. Most common was the use of oral calcium products (40/115 herds), followed by feeding of anionic salts in the close-up diet $(10 / 115$ herds). These results indicate that the prevalence of clinical and subclinical hypocalcemia in German dairy herds was high and that an active control strategy was
\end{abstract}

Received December 20, 2016.

Accepted July 21, 2017.

${ }^{1}$ Corresponding author: w.heuwieser@fu-berlin.de not implemented on all farms. The negative association between calcium and magnesium warrants further research regarding the physiological regulation of these 2 minerals around parturition.

Key words: subclinical hypocalcemia, milk fever, parturition, magnesium

\section{INTRODUCTION}

Periparturient hypocalcemia is a common metabolic disorder in dairy cows that leads to an increased risk of detrimental health and production outcomes and in severe cases can be life threatening. Physiologically, serum calcium concentration in the adult cow is maintained above $2.0 \mathrm{mmol} / \mathrm{L}$ (Martin-Tereso and Martens, 2014). Due to the start of colostrum production and consequently increasing calcium demand, the nadir of serum calcium concentration occurs 12 to $24 \mathrm{~h}$ after parturition (Kimura et al., 2006; Goff, 2008).

Hypocalcemia is considered as a gateway disease and predisposes the cow to various metabolic and infectious disorders in early lactation (Goff, 2008) such as metritis (Martinez et al., 2012) and mastitis (Curtis et al., 1983). In a study by Martinez et al. (2012), numbers of neutrophils were reduced and their ability to undergo phagocytosis and oxidative burst was impaired in cows affected by hypocalcemia which might in part explain the increased risk for infectious diseases. On a cellular level, suppressed function of immune cells was mediated by reduced cytosolic calcium concentration (Martinez et al., 2014).

Cows with naturally occurring hypocalcemia at parturition had elevated concentrations of NEFA and BHBA as indicators of increased lipomobilization (Martinez et al., 2012). The same group of authors were able to repeat these finding in cows with induced hypocalcemia (Martinez et al., 2014). Induction of hypocalcemia with EDTA infusion caused reduced DMI and decreased plasma concentrations of insulin. These negative effects are supported by other studies showing an increased risk for displaced abomasum (Chapinal et al., 2011; Seifi et al., 2011), increased weight loss in 
early lactation (Caixeta et al., 2015), and ultimately an increased culling risk (Seifi et al., 2011; Roberts et al., 2012) for cows with hypocalcemia. Furthermore, subclinical hypocalcemia affected reproductive performance such as estrous cyclicity (Ribeiro et al., 2013; Caixeta et al., 2017) and pregnancy rate to first AI (Chapinal et al., 2012).

In a retrospective study including 1,462 cows from 480 dairy farms in 21 states of the United States, the prevalence of hypocalcemia was $25 \%$ in first lactation cows and about $50 \%$ in multiparous cows (Reinhardt et al., 2011). Clinical milk fever was prevalent in 1, 4, 6 , and $10 \%$ of first, second, third, and $\geq$ fourth lactation cows, respectively. These results originate from the 2002 National Animal Health Monitoring System (NAHMS) dairy study (USDA, 2002). This study has been used as a reference for the prevalence of hypocalcemia multiple times. But the study was not specifically designed to estimate cow- and herd-level prevalence of hypocalcemia and the currentness of the results are limited.

More recently, different strategies (e.g., oral calcium supplementation, anionic salts) to prevent hypocalcemia have evolved and were implemented in the dairy industry (Martin-Tereso and Martens, 2014). These approaches might affect the prevalence of hypocalcemia. To our knowledge, however, no information is available reporting the actual prevalence of hypocalcemia and associated preventive strategies.

Therefore, the objective of this study was to estimate the prevalence of hypocalcemia on a cow level and the implemented preventive strategies to control for hypocalcemia in commercial German dairy herds.

\section{MATERIALS AND METHODS}

The experimental procedures reported herein were conducted with the approval of the Institutional Animal Care and Use Committee of the Freie Universität Berlin.

\section{Study Population}

A cross-sectional study was conducted based on a convenience sample of 115 dairy herds from 8 federal states of Germany between February 2015 and August 2016. Inclusion criteria for herds were (1) participation in a federal DHIA testing system, (2) freestall housing with at least 100 milking cows, (3) feeding of a TMRbased diet, and (4) a computerized herd management software. Average herd size was 513 and ranged from 112 to 2,607 lactating cows. The average milk produc- tion (305-d ECM, $4.0 \%$ fat, $3.4 \%$ protein) was $9,231 \mathrm{~kg}$ (range 6,257-10,880 kg). Holstein Friesian cows were the dominant breed on 112 farms. Two farms kept Simmental cattle and 1 farm Jersey as the dominant breed.

A sample size calculation was conducted according to Dohoo et al. (2009). We assumed that the prevalence of milk fever tends to be highly clustered within herds because of the effect of herd management (e.g., breed, dry cow nutrition) on the risk of hypocalcemia. Therefore, we selected an intra-cluster correlation coefficient of 0.3 . A sample size of 1,388 animals with 12 animals per herd was deemed adequate to estimate the true prevalence of subclinical hypocalcemia on a cow level with $95 \%$ confidence and $10 \%$ precision.

If a farm provided less than 12 blood samples the farm was excluded from statistical analysis. If a farm supplied more than 12 blood samples, 12 cows were selected, using a random function in Excel (Office 2010, Microsoft Deutschland Ltd., Munich, Germany). A random list was generated separately for each of the farms.

\section{Experimental Procedures}

Veterinary practitioners had been invited to participate in the study by an information leaflet sent out by regular mail. Participating practices were informed about the nature and duration of the study and received a package containing serum blood collection systems (SMonovette $9 \mathrm{~mL} \mathrm{Z}$, Sarstedt AG and Co, Nürnbrecht, Germany), cryo-vials (Cryvial, Carl Roth $\mathrm{GmbH}$ and Co. KG, Karlsruhe, Germany) to store serum at $-20^{\circ} \mathrm{C}$ until analysis, and a written standard operating procedure. This standard operating procedure described which information to record for each cow enrolled and how to examine the cow before blood collection. A case report form for each cow was provided to document time of sampling, ear tag number, time of calving, calving ease (i.e., unassisted calving or assisted calving with at least one person), clinical symptoms of milk fever (i.e., recumbency), and parity. Administration of calcium products, time relative to calving, and route of administration (i.e., subcutaneous, intravenous, oral) of these products was also documented. Sampling 12 cows per herd, veterinarians were asked to include 4 primiparous cows into the cohort. The farm personnel was asked, if other preventive strategies, such as feeding of anionic salts in the close-up group or injection of vitamin $\mathrm{D}$ before calving were implemented.

Animals were enrolled by convenience when a veterinarian visited the farm on a given day and an animal met the inclusion criteria of being within $48 \mathrm{~h}$ after parturition. 


\section{Definition of Hypocalcemia on Cow Level and Herd Level}

Normocalcemia was defined as serum calcium concentration greater or equal to $2.0 \mathrm{mmol} / \mathrm{L}$ (Reinhardt et al., 2011). Cows not affected clinically but with a serum calcium concentration below $2.0 \mathrm{mmol} / \mathrm{L}$ were categorized as subclinical hypocalcemic animals. Recumbent cows with a serum calcium concentration below $2.0 \mathrm{mmol} / \mathrm{L}$ were defined as cows suffering from clinical milk fever. Although often used in current literature (Reinhardt et al., 2011; Wilhelm et al., 2017) it was recently shown that $2.0 \mathrm{mmol} / \mathrm{L}$ is the most conservative approach as higher thresholds (i.e., 2.1 and $2.2 \mathrm{mmol} / \mathrm{L}$ ) were also associated with negative health or production outcomes (Chapinal et al., 2011; Seifi et al., 2011; Chapinal et al., 2012; Martinez et al., 2012; Roberts et al., 2012). Therefore, analyses were conducted considering 3 thresholds (i.e., 2.0, 2.1, and $2.2 \mathrm{mmol} / \mathrm{L}$ ).

Based on the results of the sampled cohort per farm, herds were categorized as negative ( $\leq 2$ animals per herd with serum calcium concentration below the threshold), borderline ( 3 to 5 animals per herd with serum calcium concentration below the threshold), or positive ( $\geq 6$ animals per herd with serum calcium concentration below the threshold) according to Cook et al. (2006). Using a confidence level of $75 \%$ and an alarm level of $30 \%$, the sampling of 12 animals per herd is adequate to classify herds into 3 categories (Figure 1).

\section{Blood Sampling and Laboratory Analyses}

Blood samples were taken from the coccygeal vessels using a serum blood collection system. Samples were kept at room temperature and allowed to clot. Within $5 \mathrm{~h}$ of blood collection, samples were centrifuged to harvest serum, which was frozen at $-20^{\circ} \mathrm{C}$. Analysis of blood samples was carried out by a commercial laboratory (Synlab Services GmbH, Augsburg, Germany). Total serum calcium, magnesium, and phosphorus concentration was analyzed using photometry (AU680, Beckman Coulter, Krefeld, Germany). The interassay coefficient of variation was $1.03 \%$ (Ca $2.37 \mathrm{mmol} / \mathrm{L}$; $\mathrm{n}=16), 1.06 \%(\mathrm{Mg}=0.99 \mathrm{mmol} / \mathrm{L} ; \mathrm{n}=16)$, and $2.43 \%(\mathrm{P}=0.83 \mathrm{mmol} / \mathrm{L} ; \mathrm{n}=16)$ for calcium, magnesium, and phosphorus, respectively. The intraassay coefficient of variation was $1.19 \%$ (Ca $2.40 \mathrm{mmol} / \mathrm{L} ; \mathrm{n}$ $=10), 0.88 \%(\mathrm{Mg}=0.99 \mathrm{mmol} / \mathrm{L} ; \mathrm{n}=10)$, and $1.03 \%$ $(\mathrm{P}=0.85 \mathrm{mmol} / \mathrm{L} ; \mathrm{n}=10)$ for calcium, magnesium, and phosphorus, respectively.

\section{Statistical Analyses}

Individual cow data were transferred to Microsoft Excel (Office 2013, Microsoft Deutschland Ltd.). Statis-

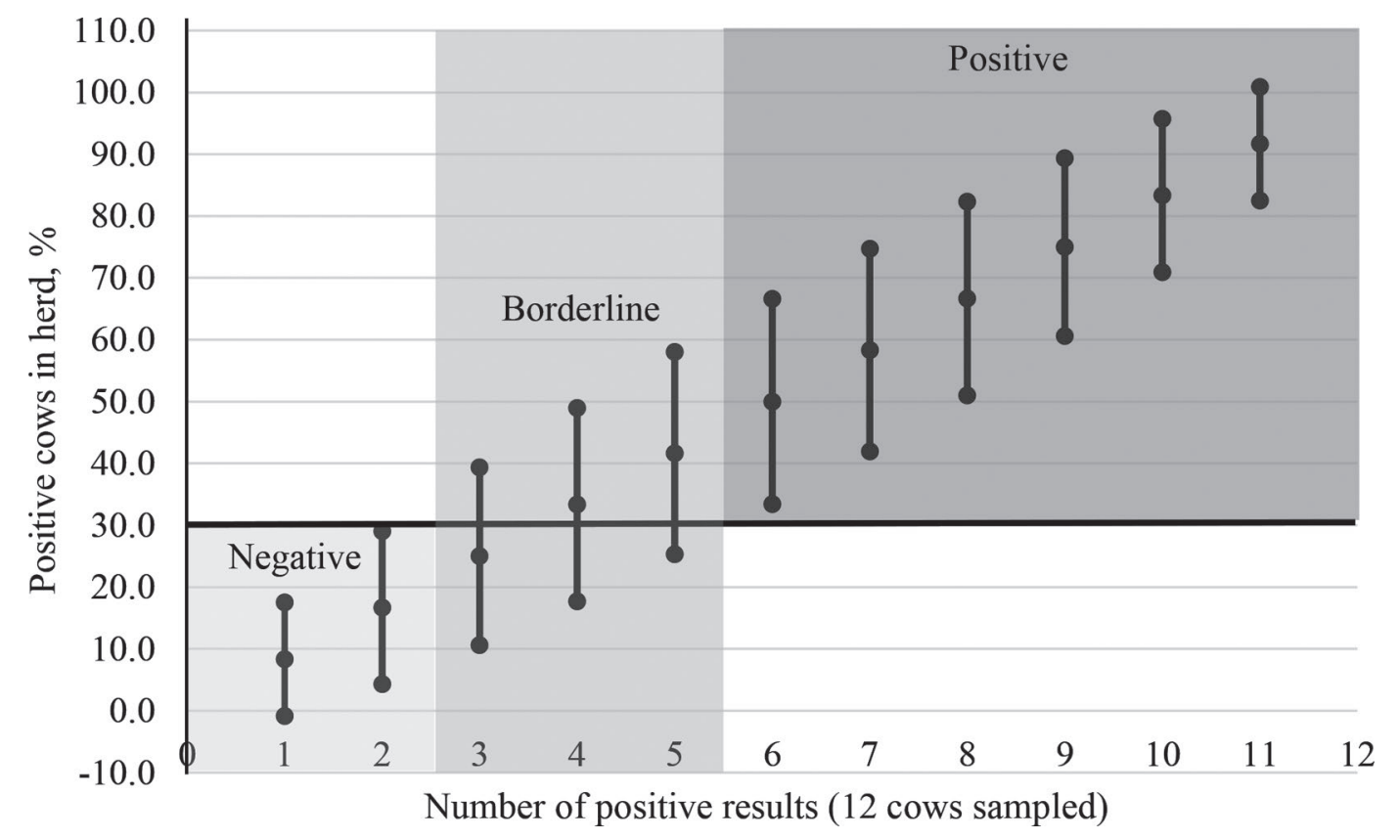

Figure 1. Classification of blood calcium concentrations using $75 \%$ CI and an alarm level of $30 \%$ for test results from 12 cows sampled from a group of 100 cows. This calculation illustrates the association between positive blood samples in the cohort and prevalence of hypocalcemia in the tested herd. 
Table 1. Prevalence (no./total; \% in parentheses) of subclinical hypocalcemia and milk fever 0 to $48 \mathrm{~h}$ after parturition in dairy cows stratified by parity considering 3 thresholds for blood calcium

\begin{tabular}{lcccc}
\hline Type of hypocalcemia & Lactation 1 & Lactation 2 & Lactation 3 & Lactation $\geq 4$ \\
\hline Subclinical $2.0 \mathrm{mmol} / \mathrm{L}$ & $13 / 228^{\mathrm{a}}$ & $103 / 355^{\mathrm{b}}$ & $164 / 332^{\mathrm{c}}$ & $281 / 465^{\mathrm{d}}$ \\
Threshold & $(5.7)$ & $(29.0)$ & $(49.4)$ & $(60.4)$ \\
& $32 / 228^{\mathrm{a}}$ & $158 / 355^{\mathrm{b}}$ & $211 / 332^{\mathrm{c}}$ & $331 / 465^{\mathrm{d}}$ \\
Threshold $2.1 \mathrm{mmol} / \mathrm{L}$ & $(14.0)$ & $(44.5)$ & $(63.6)$ & $(71.2)$ \\
& $83 / 228^{\mathrm{a}}$ & $222 / 355^{\mathrm{b}}$ & $256 / 332^{\mathrm{c}}$ & $370 / 465^{\mathrm{bc}}$ \\
Threshold $2.2 \mathrm{mmol} / \mathrm{L}$ & $(36.4)$ & $(62.5)$ & $(77.1)$ & $(79.6)$ \\
& $0 / 228^{\mathrm{a}}$ & $5 / 355^{\mathrm{a}}$ & $19 / 332^{\mathrm{b}}$ & $75 / 465^{\mathrm{c}}$ \\
Clinical & $(0.0)$ & $(1.4)$ & $(5.7)$ & $(16.1)$ \\
& & & \\
\hline
\end{tabular}

${ }^{\mathrm{a}-\mathrm{d}}$ Values with different superscripts within rows differ, $P<0.05$.

tical analyses were performed using SPSS for Windows (version 22.0, SPSS Inc., IBM, Ehningen, Germany). The association of lactation number and the type of hypocalcemia or the type of individual preventive strategy was analyzed using cross tabulations and $\chi^{2}$ tests.

For evaluation of the association between serum calcium concentration and time of calving, ease of calving, and time interval from calving to sampling, we used the GENLINMIXED procedure of SPSS. Cow was the experimental unit and herd was considered as a random effect. According to the model-building strategies described by Dohoo et al. (2009), each parameter considered for the mixed model should be separately analyzed in a univariate model, including the parameter as a fixed factor (i.e., categorical parameter) or covariate (i.e., continuous parameter). Only parameters resulting in univariate models with $P \leq 0.2$ should be included in the final mixed model. The initial model contained the following explanatory variables as fixed effects: parity $(1,2,3, \geq 4)$, breed (Holstein, Jersey, or Simmental), time of calving (daytime from 0600 to $1759 \mathrm{~h}$ vs. nighttime 1800 to $0559 \mathrm{~h}$ ), calving ease (unassisted calving vs. assisted calving), and time interval from calving to sampling (continuous; 0 to $48 \mathrm{~h}$ ).

The concentration of calcium was related to the concentration of phosphorus or magnesium using a linear regression model and the LINEAR REGRESSION procedure from SPSS: $y_{i}=a+b X_{i}$, where $y_{i}$ is the dependent variable (magnesium or phosphorous concentration), $\mathrm{X}_{\mathrm{i}}$ is the independent variable (calcium concentration), $\mathrm{b}$ is the slope of the regression line, and $a$ is the intercept. $R^{2}$ describes the coefficient of determination, which is the relative proportion of variance in $\mathrm{y}_{\mathrm{i}}$ that can be explained by $\mathrm{X}_{\mathrm{i}}$.

\section{RESULTS}

Overall, blood samples were drawn from 1,709 animals at 0 to $48 \mathrm{~h}$ after calving from 125 farms. Ten farms with 54 animals were excluded from analysis because they provided less than 12 samples per farm.
Another 275 animals were randomly excluded because 60 farms provided more than 12 samples per farm.

Data of 1,380 animals were available for final analyses. Of those, 228 (16.5\%), 355 (25.7\%), $332(24.1 \%)$, and $465(33.7 \%)$ were in first, second, third, and $\geq$ fourth lactation, respectively.

Based on a calcium threshold of $2.0 \mathrm{mmol} / \mathrm{L}$ and clinical signs, the prevalence of subclinical hypocalcemia and clinical milk fever was $40.7 \%(561 / 1,380)$ and $7.2 \%(99 / 1,380)$, respectively. Considering higher thresholds of 2.1 and $2.2 \mathrm{mmol} / \mathrm{L}$, prevalence of subclinical hypocalcemia increased to $53.0 \%(732 / 1380)$ and $67.5 \%(931 / 1380)$, respectively (Table 1$)$. The prevalence of hypocalcemia increased with parity. None of the cows in first lactation was suffering from clinical milk fever. Prevalence of clinical milk fever was $1.4 \%$ (5/355), $5.7 \%$ (19/332), and $16.1 \%$ (75/465) for second, third, and $\geq$ fourth parity cows, respectively (Table 1 ).

A significant effect of parity $(P<0.001)$ was observed on serum calcium concentration. Cows in first, second, third, or $\geq$ fourth lactation had a serum calcium concentration of $2.213 \mathrm{mmol} / \mathrm{L}$ (95\% CI: 2.054-2.372), $2.102 \mathrm{mmol} / \mathrm{L}$ (95\% CI: 1.942-2.262), $1.997 \mathrm{mmol} / \mathrm{L}$ (95\% CI: $1.837-2.158)$, and $1.891 \mathrm{mmol} / \mathrm{L}$ (95\% CI: 1.735-2.046), respectively. Serum calcium concentration of cows that calved at night was $0.087 \mathrm{mmol} / \mathrm{L}$ higher compared with cows that calved during the day (95\% CI: $0.044-0.130 ; P=0.001)$. No significant effect of breed $(P=0.811)$, time from calving to sampling $(P$ $=0.288)$, or calving ease $(P=0.902)$ was observed on serum calcium concentration.

A negative association of serum calcium and serum magnesium concentration was observed $(\mathrm{y}=-0.208 \mathrm{x}$ $+1.454 ; \mathrm{R}^{2}=0.151 ; P<0.001 ;$ Figure 2$)$. In contrast, there was a positive association of serum calcium and serum phosphorus concentration $(\mathrm{y}=0.900 \mathrm{x}-0.229$; $\mathrm{R}^{2}=0.335 ; P<0.001 ;$ Figure 3 ).

Prevention of hypocalcemia on a cow level was more prevalent in multiparous cows compared with primiparous cows. Oral calcium supplementation was implemented in 13.8, 24.1, and 26.0\% in second, third, and 


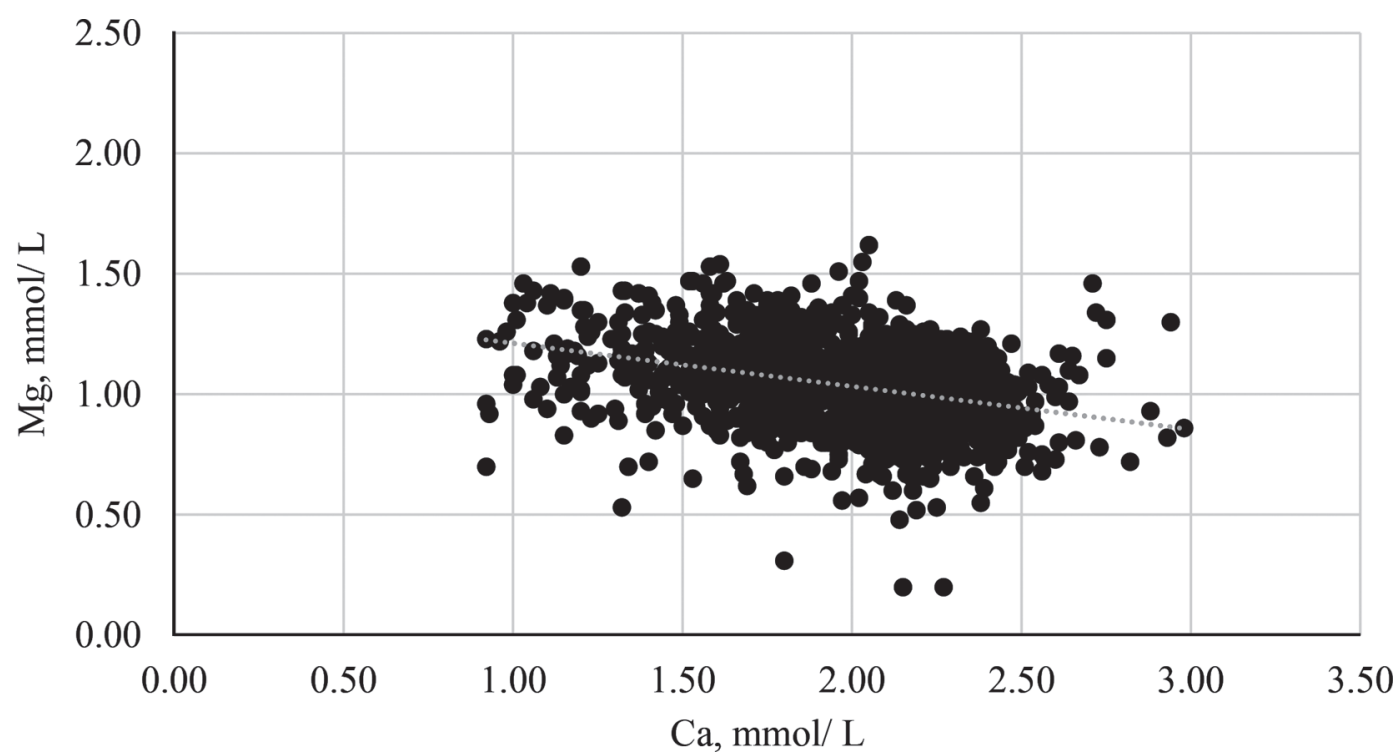

Figure 2. Association between serum calcium and serum magnesium concentration for all cows $\left(\mathrm{n}=1,380, \mathrm{y}=-0.208 \mathrm{x}+1.454 ; \mathrm{R}^{2}=\right.$ $0.151 ; P<0.001)$.

$\geq$ fourth parity cows (Table 2) and most prevalent for prevention of hypocalcemia at the cow-level $(\mathrm{n}=255$; Table 2). Subcutaneous calcium injection or prepartum vitamin $\mathrm{D}$ application played a minor role and was on the herd level always combined with another preventive strategy (Table 2). In 34.8\% (40/115), 6.1\% (7/115), and $2.6 \%(3 / 115)$ of the herds, oral calcium supplementation, anionic salts, or a combination of both was used to control hypocalcemia on a herd level, respectively. Most of the herds (65/115) did not implement a control strategy for hypocalcemia.
Only $12.2 \%$ of the 115 herds enrolled were classified as negative based on the alarm levels set by Cook et al. (2006).

\section{DISCUSSION}

\section{Study Results}

The results from the present study indicate that the prevalence of hypocalcemia within $48 \mathrm{~h}$ after parturition in TMR-fed, freestall dairy herds in Germany was

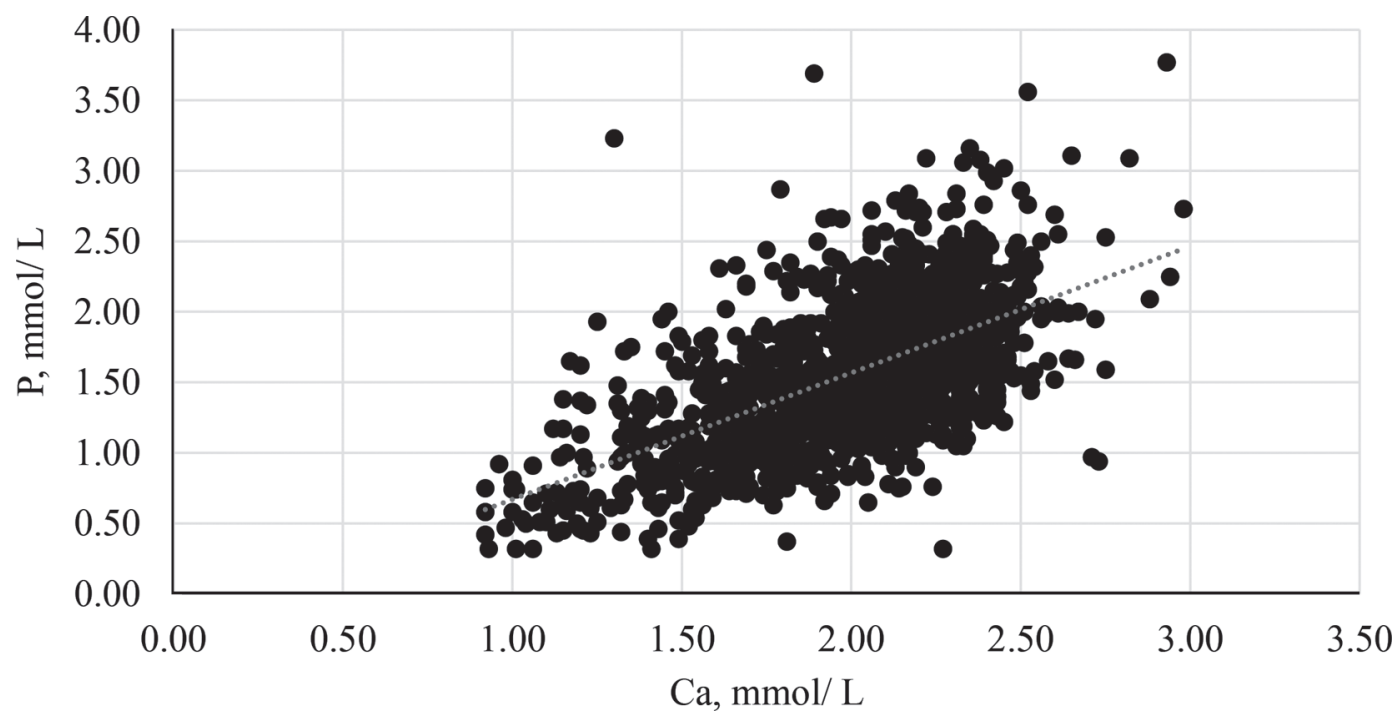

Figure 3. Association between serum calcium and serum phosphorus concentration for all cows $\left(\mathrm{n}=1,380, \mathrm{y}=0.900 \mathrm{x}-0.229 ; \mathrm{R}^{2}=0.335\right.$; $P<0.001)$. 
high, particularly in multiparous cows. In contrast, preventive strategies were not consistently implemented on the farms.

Cows with a serum calcium concentration below 2.0 $\mathrm{mmol} / \mathrm{L}$ were considered as hypocalcemic. Although this is a conservative threshold, it is well accepted in research and applied in the field (DeGaris and Lean, 2008; Reinhardt et al., 2011; Wilhelm et al., 2017). Recent studies suggested higher thresholds. It was shown that hypocalcemia using 2.1, 2.2, and $2.3 \mathrm{mmol} / \mathrm{L}$ thresholds was associated with a negative health outcome such as displaced abomasum and metritis (Chapinal et al., 2011, 2012; Martinez et al., 2012) or an increased culling risk (Seifi et al., 2011; Roberts et al., 2012). These studies, however, considered a longer risk period postpartum (i.e., of 3 to 7 DIM). Although these epidemiological studies showed an association and also some evidence for a causal relationship between hypocalcemia and an increased risk for infectious diseases (Martinez et al., 2014), one has to be careful when evaluating longer risk periods. It is also plausible that reduced feed intake before clinical signs of disease can affect serum calcium levels as most recently shown by Pinedo et al. (2017) for cows suffering from puerperal metritis. At calving, no difference was present in serum calcium concentration between healthy and metritic cows. On the day of diagnosis (on average 6.1 DIM), however, serum calcium concentration was lower in cows with puerperal metritis $(1.57 \mathrm{mmol} / \mathrm{L})$ compared with healthy cows $(2.10 \mathrm{mmol} / \mathrm{L})$. To reflect higher thresholds, we calculated the prevalence accordingly. Table 1 shows that a mild increase of the threshold leads to a dramatic increase of animals considered as hypocalcemic. Further evaluations are necessary to define the most appropriate threshold of hypocalcemia within this time period.

In our study, $47.6 \%$ of multiparous cows suffered from subclinical hypocalcemia within $48 \mathrm{~h}$ after parturition. This finding is in agreement with others (Reinhardt et al., 2011; Gild et al., 2015; Miltenburg, 2015). The inability of the cow to maintain normal serum calcium concentration is caused by a maladaptation of the mineral metabolism in response to an increased demand for calcium. Dairy cows need around $20 \mathrm{~g}$ of calcium per day at the end of the dry period. With colostrum production, the demand increases to 30 to $70 \mathrm{~g}$ per day depending on milk yield. The mechanisms to decrease urinary calcium excretion, to increase absorption of calcium from the gut, and to upregulate calcium release from bone tissue, however, take about $48 \mathrm{~h}$, which may lead to insufficient calcium supply in this period (Martin-Tereso and Martens, 2014).

Surprisingly, serum calcium concentration of cows that calved at night was higher than serum calcium concentration of cows that calved during the day. The effect, however, was biologically small and without an apparent explanation.

In contrast to multiparous cows, hypocalcemia was rarely found in primiparous cows (5.7\%), which is in agreement with a previously described prevalence of $2 \%$ for primiparous cows from 7 herds in Canada using the same threshold (Miltenburg, 2015). Overall, there are, however, conflicting reports on the prevalence of hypocalcemia in primiparous cows. Reinhardt et al. (2011) observed a prevalence of $25 \%$ from 480 herds in the United States. The reason for this difference remains speculative. The latter report used samples drawn for the 2002 NAHMS study. The understanding of the transition cow biology improved in the last $15 \mathrm{yr}$ and led to the implementation of preventive strategies to control milk fever. As stated in the NAHMS 2002 report (USDA, 2002), $14.3 \%$ of heifers and $19.1 \%$ of cows were fed anionic salts in their close-up diets. In the more recent NAHMS report, $20.7 \%$ of heifers and $27.6 \%$ of cows were fed anionic salts (USDA, 2014). This might be an indication of an increased awareness for prevention of milk fever and subclinical hypocalcemia. Furthermore, management practices and production conditions for heifers might have changed in the meantime (e.g., close up feeding, milk yield, feed intake).

A plausible explanation for the higher prevalence of subclinical hypocalcemia in multiparous cows is that

Table 2. Type of prophylaxis (no./total; $\%$ in parentheses) to prevent hypocalcemia in 1,380 cows of 115 dairy herds considering parity

\begin{tabular}{lcccc}
\hline Type of prophylaxis & Lactation 1 & Lactation 2 & Lactation 3 & Lactation $\geq 4$ \\
\hline Oral calcium & $5 / 228^{\mathrm{a}}$ & $49 / 355^{\mathrm{b}}$ & $80 / 332^{\mathrm{c}}$ & $121 / 465^{\mathrm{c}}$ \\
Subcutaneous calcium & $(2.2)$ & $(13.8)$ & $(24.1)$ & $(26.0)$ \\
& $0 / 228^{\mathrm{a}}$ & $7 / 355^{\mathrm{ab}}$ & $14 / 332^{\mathrm{b}}$ & $23 / 465^{\mathrm{b}}$ \\
Vitamin D prepartum & $(0.0)$ & $(2.0)$ & $(4.2)$ & $(4.9)$ \\
& $0 / 228^{\mathrm{ab}}$ & $0 / 355^{\mathrm{b}}$ & $7 / 332^{\mathrm{ac}}$ & $15 / 465^{\mathrm{c}}$ \\
Overall & $(0.0)$ & $(0.0)$ & $(2.1)$ & $(3.2)$ \\
& $5 / 228$ & $56 / 355$ & $101 / 332$ & $159 / 465$ \\
& $(2.2)$ & $(15.8)$ & $(30.4)$ & $(34.2)$ \\
\hline
\end{tabular}

${ }^{\mathrm{a}-\mathrm{c}}$ Values with different superscripts within rows differ, $P<0.05$. 
these animals have a higher calcium output due to an increased amount of colostrum compared with primiparous cows (Klingbeil, 2015). The calcium output, however, does not explain the increase in prevalence of hypocalcemia within multiparous cows with increasing age as their colostrum yield was not different. The parity-associated increase might be related to a reduced bone remodeling in multiparous cows due to a reduction of the number of active osteoclasts and osteoblasts. These cells must be recruited from progenitor cells in response to parathyroid hormone (PTH) secretion, leading to a delay in calcium mobilization (Goff, 2014).

In a recent study, 51, 54, and $42 \%$ of fourth, fifth, and sixth parity cows suffered from subclinical hypocalcemia, respectively (Reinhardt et al., 2011). These results are almost identical to our observations of 52.1, 51.1 , and $41.7 \%$ for fourth, fifth, and sixth parity cows, respectively. Prevalence of clinical milk fever in our data set $(13.4,15.0$, and $21.7 \%$ for fourth, fifth, and $\geq$ sixth parity, respectively), however, was higher than described for the United States (10, 8, and $13 \%$ for fourth, fifth, and sixth parity, respectively; Reinhardt et al., 2011). We assume that preventive strategies are more common in the United States. In the present study, calcium was supplemented orally (40 herds) or subcutaneously ( 13 herds) in $46.1 \%$ of the collaborating herds. Only $8.7 \%$ of the herds used anionic salts to prevent hypocalcemia. In the United States, calcium supplementation also seems to be the most common strategy to prevent hypocalcemia. Based on the recent NAHMS report, 68.9 and $27.6 \%$ of the participating herds used calcium products and anionic salts, respectively (USDA, 2014). A trend was observed for large dairy farms ( $\geq 500$ milking cows) to use calcium supplementation and anionic salts more often than smaller operations.

German farmers favored oral calcium supplementation as a preventive strategy (Table 2). Sound evidence is available about the efficacy of oral calcium supplementation to prevent hypocalcemia (Sampson et al., 2009; Oetzel and Miller, 2012; Blanc et al., 2014; Martinez et al., 2016). Furthermore, economic advantages have been demonstrated (McArt and Oetzel, 2015). Based on a simulation with 1,000 calvings per year, a farm can expect an average net gain ranging from $\$ 3,000$ to $\$ 8,000$ after postpartum supplementation of oral calcium to multiparous animals. In the present study, cows in their third or greater lactation were predominantly supplemented with oral calcium products. It is noteworthy, however, that dairy farmers did not consider higher risk for hypocalcemia in older animals as the percentage of supplemented cows was almost the same for cows in lactation $3(30 \%)$ or higher (34\%).
Calving ease had no significant effect on serum calcium concentration. Because evidence indicates that primiparous cows have higher serum calcium concentrations, this finding might be confounded as presence of dystocia is more prevalent in primiparous cows (Mee, 2004; USDA, 2010).

Comparing different breeds, serum calcium concentration did not differ among Holstein, Simmental, and Jersey cows. These results must be interpreted with caution, as only 1 and 2 farms kept Jersey and Simmental cows as their dominant breed, respectively.

Serum calcium and magnesium concentration were negatively associated. Cows suffering from hypocalcemia had higher serum magnesium concentration (Figure 2). This seems to be contradictory as magnesium is considered as an important prerequisite for proper PTH-receptor function (Goff, 2014). Renal excretion of magnesium depends on oral magnesium intake and the concentration of PTH (Martin-Tereso and Martens, 2014). In a period of low serum calcium concentration, PTH is secreted into the blood, leading to calcium retention in the kidneys and increased resorption of calcium in the gut via production of 1,25-dihydroxyvitamin D. Our findings are in agreement with a previous assumption, that PTH secretion raises the threshold for renal magnesium excretion, resulting in a higher serum magnesium concentration (Goff, 2008).

In contrast, serum phosphorus concentration was low in cows suffering from hypocalcemia (Figure 3). Mechanisms of phosphorus regulation are not fully understood yet. Also, the role of hypophosphatemia in recumbent cows remains speculative. A 21-mo-long feeding trial with a diet restricted in phosphorus $(2.4$ $\mathrm{g} / \mathrm{kg}$ ) led to reduced DMI, milk yield, and BW, but did not result in recumbency (Valk and Sebek, 1999). Recently, it has been shown, however, that the presence of PTH in hypocalcemic cows increased phosphorus excretion through urine and saliva (Grünberg, 2014). A reduction of DMI prepartum can also cause insufficient phosphorus uptake through the diet and contribute to phosphorus depletion. Similar to the decrease of calcium around parturition, the major reason for hypophosphatemia is the production of colostrum and milk, as approximately $1 \mathrm{~g}$ of phosphorus is excreted in every kilogram of milk (Goff, 1999; Grünberg, 2014).

\section{Study Limitations}

The objective of this study was to characterize the cow-level prevalence of clinical and subclinical hypocalcemia in German dairy herds. To achieve this objective, 115 farms of 8 federal states from Germany were enrolled through veterinary practitioners that had been asked to collaborate in this multi-center study. 
As in many other studies determining prevalences for hyperketonemia (e.g., Ospina et al., 2010; Chapinal et al., 2012; Suthar et al., 2013) or hypocalcemia (Gild et al., 2015; Miltenburg, 2015), the dairy farms enrolled constitute a convenience sample. It is difficult to conclude if the participating dairies are representative for all dairies of the given region. In fact, the selection of herds might have been biased by an underlying interest to participate stimulated by a previous history with the condition at hand. The objective was not to compare within-herd-level prevalences of hypocalcemia because the confidence interval for the prevalence estimate is wide using only 12 samples. Rather, we wanted to categorize herds based on the proportion of positive samples (i.e., blood calcium below threshold) into negative $(0$ to $2 / 12)$, borderline ( 3 to $5 / 12)$, or positive $(\geq$ $6 / 12)$. Such classification is appropriate using 12 cows per herd based on the assumptions provided by Oetzel (2004) using a $75 \%$ confidence interval and an alarm level of $30 \%$ (Figure 1). For practitioners or consultants, this might be an adequate approach to screen a herd for the presence of subclinical hypocalcemia. As obvious from our results, many herds were classified as borderline (44.3\%). In such case, we would advise to draw more samples to classify the herd more appropriately. Although the probability to misclassify a herd decreases with increasing sample size, it is the nature of the disease with a very short risk period ( 0 to $48 \mathrm{~h}$ ) that limits this approach. In a 1,000 cow dairy, only 5.5 animals are at risk of being sampled for evaluation of hypocalcemia on any given day.

Our study design is not appropriate to give a wellfounded statement on blood calcium dynamics postpartum, due to the sampling time of 0 to $48 \mathrm{~h}$ postpartum and frequency of sampling (1 sample per cow). Recent studies with a repeated measurement in individual cows (Blanc et al., 2014; Caixeta et al., 2017) are more suitable to illustrate the effect of time of sampling on serum calcium concentration.

Based on our inclusion criteria, small dairy farms $(<100$ cows per farm) were not investigated. Therefore, this study might underestimate the true prevalence of hypocalcemia as the implementation of preventive strategies was more common in large dairy operations in the United States (USDA, 2014).

To represent common herd demographics, veterinarians were asked to include approximately one-third of primiparous cows in the samples per farm. In our study, $16.5 \%$ of the sampled animals were primiparous cows. This is not representative for the participating German dairy herds as the average percentage of primiparous cows per herd was $32.2 \%$ and the overall percentage of primiparous cows in Germany was 35.5\% (Arbeitsverband Deutscher Rinderzüchter, 2016). A possible explanation for this disagreement might be that participating veterinarians were aware that hypocalcemia is more prevalent in multiparous cows and therefore preferred to sample these cows. As indicated by our results, primiparous cows did not suffer from clinical milk fever at all and rarely from subclinical hypocalcemia. To estimate the level of hypocalcemia on a farm, we would recommend focusing on multiparous cows to reflect their higher risk of suffering from hypocalcemia.

\section{CONCLUSIONS}

Based on a convenience sample using 115 TMR-fed, freestall herds from Germany with 1,380 cows sampled within $48 \mathrm{~h}$ after parturition the prevalence of hypocalcemia was estimated. Overall, the present study indicates that periparturient hypocalcemia is a prevalent metabolic disorder on dairy farms as 47.6 and $8.6 \%$ of multiparous cows suffered from subclinical hypocalcemia and clinical milk fever, respectively. For primiparous cows the prevalence of subclinical hypocalcemia was $5.7 \%$. An active control strategy was implemented only on $43.5 \%$ of the farms. Oral calcium supplementation at parturition was the most predominant preventive strategy, particularly in multiparous cows (21.7\%). The negative association between calcium and magnesium was an interesting finding that warrants further research into the physiologic regulation of these 2 minerals at parturition. The results of this study are based on a large number of herds with different managerial conditions and seem to be applicable to high producing dairy herds.

\section{ACKNOWLEDGMENTS}

The authors thank the collaborating practitioners and the farm personnel for their kind support. This study was funded in part by Tiergyn e.V. (Berlin, Germany).

\section{REFERENCES}

Arbeitsverband Deutscher Rinderzüchter. 2016. Rinderproduktion in Deutschland 2015. Arbeitsgemeinschaft Deutscher Rinderzüchter e.V. (ADR), Bonn, Germany.

Blanc, C. D., M. Van der List, S. S. Aly, H. A. Rossow, and N. Silvadel-Rio. 2014. Blood calcium dynamics after prophylactic treatment of subclinical hypocalcemia with oral or intravenous calcium. J. Dairy Sci. 97:6901-6906.

Caixeta, L. S., P. A. Ospina, M. B. Capel, and D. V. Nydam. 2015. The association of subclinical hypocalcemia, negative energy balance and disease with bodyweight change during the first 30 days post-partum in dairy cows milked with automatic milking systems. Vet. J. 204:150-156.

Caixeta, L. S., P. A. Ospina, M. B. Capel, and D. V. Nydam. 2017. Association between subclinical hypocalcemia in the first 3 days of lactation and reproductive performance of dairy cows. Theriogenology https://doi.org/10.1016/j.theriogenology.2017.01.039. 
Chapinal, N., M. Carson, T. F. Duffield, M. Capel, S. Godden, M. Overton, J. E. Santos, and S. J. LeBlanc. 2011. The association of serum metabolites with clinical disease during the transition period. J. Dairy Sci. 94:4897-4903.

Chapinal, N., M. E. Carson, S. J. LeBlanc, K. E. Leslie, S. Godden, M. Capel, J. E. Santos, M. W. Overton, and T. F. Duffield. 2012. The association of serum metabolites in the transition period with milk production and early-lactation reproductive performance. J. Dairy Sci. 95:1301-1309.

Cook, N., G. Oetzel, and K. Nordlund. 2006. Modern techniques for monitoring high-producing cows 2. Practical applications. In Pract. 28:598-603.

Curtis, C. R., H. N. Erb, C. J. Sniffen, R. D. Smith, P. A. Powers, M. C. Smith, M. E. White, R. B. Hillman, and E. J. Pearson. 1983 Association of parturient hypocalcemia with eight periparturient disorders in Holstein cows. J. Am. Vet. Med. Assoc. 183:559-561.

DeGaris, P. J., and I. J. Lean. 2008. Milk fever in dairy cows: A review of pathophysiology and control principles. Vet. J. 176:58-69.

Dohoo, I. R., S. W. Martin, and H. Stryhn. 2009. Veterinary Epidemiologic Research. 2nd ed. University of Prince Edward Island, Charlottetown, PEI, Canada.

Gild, C., N. Alpert, and M. van Straten. 2015. The influence of SCH on milk production and reproduction in Israeli dairy herds. Isr. J. Vet. Med. 70:16-21.

Goff, J. P. 1999. Treatment of calcium, phosphorus, and magnesium balance disorders. Vet. Clin. North Am. Food Anim. Pract. 15:619-639.

Goff, J. P. 2008. The monitoring, prevention, and treatment of milk fever and subclinical hypocalcemia in dairy cows. Vet. J. 176:50-57.

Goff, J. P. 2014. Calcium and magnesium disorders. Vet. Clin. North Am. Food Anim. Pract. 30:359-381.

Grünberg, W. 2014. Treatment of phosphorus balance disorders. Vet. Clin. North Am. Food Anim. Pract. 30:383-408.

Kimura, K., T. A. Reinhardt, and J. P. Goff. 2006. Parturition and hypocalcemia blunts calcium signals in immune cells of dairy cattle. J. Dairy Sci. 89:2588-2595.

Klingbeil, M. 2015. Investigation of influence factors on yield, quality and calcium content of first colostrum in Holstein. Doctoral thesis. Ruminant and Swine Clinic, Faculty of Veterinary Medicin, Freie Universität Berlin, Germany.

Martin-Tereso, J., and H. Martens. 2014. Calcium and magnesium physiology and nutrition in relation to the prevention of milk fever and tetany (dietary management of macrominerals in preventing disease). Vet. Clin. North Am. Food Anim. Pract. 30:643-670.

Martinez, N., C. A. Risco, F. S. Lima, R. S. Bisinotto, L. F. Greco, E. S. Ribeiro, F. Maunsell, K. Galvao, and J. E. Santos. 2012. Evaluation of peripartal calcium status, energetic profile, and neutrophil function in dairy cows at low or high risk of developing uterine disease. J. Dairy Sci. 95:7158-7172.

Martinez, N., L. D. Sinedino, R. S. Bisinotto, R. Daetz, C. A. Risco, K. N. Galvao, W. W. Thatcher, and J. E. Santos. 2016. Effects of oral calcium supplementation on productive and reproductive performance in Holstein cows. J. Dairy Sci. 99:8417-8430.

Martinez, N., L. D. Sinedino, R. S. Bisinotto, E. S. Ribeiro, G. C. Gomes, F. S. Lima, L. F. Greco, C. A. Risco, K. N. Galvao, D. Taylor-Rodriguez, J. P. Driver, W. W. Thatcher, and J. E. Santos. 2014. Effect of induced subclinical hypocalcemia on physiological responses and neutrophil function in dairy cows. J. Dairy Sci. 97:874-887.

McArt, J. A., and G. R. Oetzel. 2015. A stochastic estimate of the economic impact of oral calcium supplementation in postparturient dairy cows. J. Dairy Sci. 98:7408-7418.
Mee, J. F. 2004. Managing the dairy cow at calving time. Vet. Clin. North Am. Food Anim. Pract. 20:521-546.

Miltenburg, C. L. 2015. Management of peripartum dairy cows for metabolic health and immune function. Doctoral Thesis. Department of Population Medicine, University of Guelph, Ontario, Canada.

Oetzel, G. R. 2004. Monitoring and testing dairy herds for metabolic disease. Vet. Clin. North Am. Food Anim. Pract. 20:651-674.

Oetzel, G. R., and B. E. Miller. 2012. Effect of oral calcium bolus supplementation on early-lactation health and milk yield in commercial dairy herds. J. Dairy Sci. 95:7051-7065.

Ospina, P. A., D. V. Nydam, T. Stokol, and T. R. Overton. 2010. Associations of elevated nonesterified fatty acids and beta-hydroxybutyrate concentrations with early lactation reproductive performance and milk production in transition dairy cattle in the northeastern United States. J. Dairy Sci. 93:1596-1603.

Pinedo, P., J. Velez, G. Solano, N. Rodriguez, J. Naves, G. M. Schuenemann, and C. Risco. 2017. Effect of oral calcium administration on the cure and reproductive performance of Holstein cows diagnosed with puerperal metritis. J. Dairy Sci. 100:2917-2927. https://doi.org/10.3168/jds.2016-11577.

Reinhardt, T. A., J. D. Lippolis, B. J. McCluskey, J. P. Goff, and R. L. Horst. 2011. Prevalence of subclinical hypocalcemia in dairy herds. Vet. J. 188:122-124.

Ribeiro, E. S., F. S. Lima, L. F. Greco, R. S. Bisinotto, A. P. Monteiro, M. Favoreto, H. Ayres, R. S. Marsola, N. Martinez, W. W Thatcher, and J. E. Santos. 2013. Prevalence of periparturient diseases and effects on fertility of seasonally calving grazing dairy cows supplemented with concentrates. J. Dairy Sci. 96:5682-5697.

Roberts, T., N. Chapinal, S. J. Leblanc, D. F. Kelton, J. Dubuc, and T. F. Duffield. 2012. Metabolic parameters in transition cows as indicators for early-lactation culling risk. J. Dairy Sci. 95:30573063.

Sampson, J. D., J. N. Spain, C. Jones, and L. Carstensen. 2009. Effects of calcium chloride and calcium sulfate in an oral bolus given as a supplement to postpartum dairy cows. Vet. Ther. 10:131-139.

Seifi, H. A., S. J. Leblanc, K. E. Leslie, and T. F. Duffield. 2011. Metabolic predictors of post-partum disease and culling risk in dairy cattle. Vet. J. 188:216-220.

Suthar, V. S., J. Canelas-Raposo, A. Deniz, and W. Heuwieser. 2013 Prevalence of subclinical ketosis and relationships with postpartum diseases in European dairy cows. J. Dairy Sci. 96:2925-2938.

USDA. 2002. Part I: Reference of Dairy Cattle Health and Health Management Practices in the United States. APHIS, Fort Collins, CO.

USDA. 2010. Dairy 2007, Heifer Calf Health and Management Practices on U.S. Dairy Operations. APHIS, Fort Collins, CO.

USDA. 2014. Dairy Cattle Management Practices in the United States. APHIS, Fort Collins, CO.

Valk, H., and L. B. Sebek. 1999. Influence of long-term feeding of limited amounts of phosphorus on dry matter intake, milk production, and body weight of dairy cows. J. Dairy Sci. 82:2157-2163.

Wilhelm, A. L., M. G. Maquivar, S. Bas, T. A. Brick, W. P. Weiss, H. Bothe, J. S. Velez, and G. M. Schuenemann. 2017. Effect of serum calcium status at calving on survival, health, and performance of postpartum Holstein cows and calves under certified organic management. J. Dairy Sci. 100:3059-3067. https://doi.org/10.3168/jds .2016-11743. 